\title{
Can cover sheath model influence semen retention in AI-gun trials and pregnancy rates of cows inseminated at a fixed-time?
}

\section{A bainha utilizada na inseminação artificial (IA) pode influenciar a retenção residual de sêmen e as taxas de concepção de vacas inseminadas em tempo fixo?}

\author{
André Maciel Crespilho ${ }^{1 *}$; Lorenzo Garrido Segabinazzi²; Helton Nunes Pinto ${ }^{3}$; \\ Tiago Camargo ${ }^{3}$; Cristiano Silva Ferreira ${ }^{4}$; Igor Cavalheiro ${ }^{5}$; Kleber da Cunha \\ Peixoto Junior ${ }^{6}$; Ronaldo Aoki Cerri ${ }^{7}$
}

\section{Highlights:}

Quality of artificial insemination supplies impact the efficiency of this technique.

Cover sheath model affects semen retention in artificial insemination (AI)-gun trials.

Residual semen retention occurs regardless of cover sheath model used for AI.

Cover sheath used in AI can influence the pregnancy rates of cows.

\begin{abstract}
The achievement of satisfactory results in fixed-time artificial insemination (FTAI) protocols depends on several factors, such as the quality of the materials used to perform the artificial insemination (AI). In this context, three experiments were conducted to evaluate the effect of the cover sheath model on the residual retention of semen during AI and the pregnancy rates of cows submitted to FTAI. In Experiment 1, 400 straws of cryopreserved bovine semen were thawed and repacked in samples with similar weight and volume characteristics. Each new dose of semen $(n=300)$ was mounted using one of three AI cover sheath models $(n=100$ semen/sheath doses): the main brand in the global market $(\mathrm{G} 1)$, the main model in the Brazilian market (G2), and a model marketed as having a low residual semen retention rate (G3), to determine the percentages of seminal elimination (PSEs) during AI. In Experiment 2, 464 Nelore cows were synchronized through intravaginal progesterone implants and inseminated using the same cover sheaths as those tested in Experiment 1, which were grouped into classes (conventional: G1 and G2 [n=225]; and low reflux: G3 [n=239]). In Experiment 3, 859 Nelore cows were synchronized and inseminated as described above, using the same cover sheaths previously tested. After each AI, cover sheaths were visually inspected for the presence of residual semen and pregnancy diagnosis was
\end{abstract}

1 Prof. Dr., Programa de Mestrado em Medicina Veterinária e Bem-Estar Animal, Universidade Santo Amaro, UNISA, São Paulo, SP, Brasil. E-mail: andremacc@yahoo.com.br

2 Discente, Programa de Pós-Graduação em Biotecnologia Animal, Faculdade de Medicina Veterinária e Zootecnia, FMVZ/ UNESP, Botucatu, SP, Brasil. E-mail: lgseg@hotmail.com

3 Médicos Veterinários, Norte Consultoria Agropecuária, Coxim, MS, Brasil. E-mail: norteav@hotmail.com; tdcamargo@ hotmail.com

4 Discente, Programa de Mestrado em Medicina Veterinária e Bem-Estar Animal, UNISA, São Paulo, SP, Brasil. E-mail: cristiano_ ferr@hotmail.com

5 Médico Veterinário, Geneplan Reprodução Bovina, Campo Grande, MS, Brasil. E-mail: igor@geneplan.com.br

6 Prof. Dr., Programa de Mestrado em Medicina Veterinária e Bem-Estar Animal, Universidade Santo Amaro, UNISA, São Paulo, SP, Brasil. E-mail: kjunior@prof.unisa.br

7 Prof. Dr., Applied Animal Biology Program, Faculty of Land and Food Systems, University of British Columbia, BC, Canadá. E-mail: ronaldo.cerri@ubc.ca

* Author for correspondence 
performed 35 days after FTAI (Experiments 2 and 3). The PSEs in Experiment 1 were 91.7\%, 90.6\% and $96.5 \%$ for groups $\mathrm{G} 1, \mathrm{G} 2$ and $\mathrm{G} 3$, respectively $(P=0.05)$. The pregnancy rates in Experiment 2 were $53.33 \%$ and $58.16 \%$ for the conventional and low reflux model, respectively $(P>0.05)$, but there were differences $(\mathrm{P}=0.05)$ among the cover sheath models employed for AI $(\mathrm{G} 1$ - 57.72\% [71/123]; G2 - 48.04\% [49/102]; G3 - 58.16\% [139/239]). Additionally, a lower semen reflux incidence $(P<0.05)$ was observed in the low residual sperm retention model $(0.72 \%)$ in Experiment 3 , compared to the main international (10.42\%) and national (22.99\%) market models. In conclusion, residual semen retention occurs regardless of the cover sheath model used for AI. However, the PSE is influenced by the model and quality of cover sheath used. According to the results, the cover sheath represents a factor that may compromise the pregnancy rates of synchronized cows for FTAI.

Key words: Beef cattle. Bovine. Artificial insemination. FTAI. Conception rates.

\section{Resumo}

Diversos fatores podem influenciar os resultados de concepção dos programas de inseminação artificial em tempo-fixo (IATF), como por exemplo a qualidade dos materiais utilizados para a inseminação artificial (IA). Nesse contexto, três experimentos foram conduzidos para testar o efeito da bainha sobre o percentual de retenção residual de sêmen nos aplicadores de IA e nas taxas de concepção de vacas submetidas à IATF. No Experimento 1 foram descongeladas 400 palhetas de sêmen bovino criopreservado, que foram re-envasadas para compor amostras com características de peso e volume semelhantes. Cada nova dose de sêmen $(\mathrm{n}=300)$ foi montada em um dos três modelos de bainhas de inseminação artificial em teste (n=100 doses de sêmen/ bainha): marca líder no mercado global (G1), modelo líder no mercado brasileiro (G2), modelo comercializado como de baixa taxa de retenção residual de sêmen (G3), para determinação do percentual de eliminação seminal (PES). No Experimento-2 foram selecionadas 464 vacas Nelore, sincronizadas através de implantes intravaginais de progesterona e inseminadas empregando as mesmas bainhas do experimento anterior, porém agrupadas em classes (convencional: G1 e G2 [n=225]; ou baixo refluxo: $\mathrm{G} 3$ [ $\mathrm{n}=239]$ ). No Experimento-3 859 vacas Nelore foram sincronizadas e inseminadas com sêmen previamente selecionado, utilizando os mesmos modelos de bainhas testadas nos experimentos anteriores. Após cada IATF as bainhas foram inspecionadas visualmente para detecção de presença residual de sêmen e o diagnóstico de gestação foi realizado a partir de 35 dias após a IATF (Experimentos 2 e 3). O PES foi de 91,7\%, 90,6\% e 96,5\%, respectivamente para os grupos $\mathrm{G} 1, \mathrm{G} 2$ e G3 $(\mathrm{P}=0,05)$. As taxas de concepção no Experimento-2 foram de $53,33 \%$ e $58,16 \%$, respectivamente para o modelo convencional e de baixo refluxo $(\mathrm{P}>0,05)$, porém havendo diferenças $(\mathrm{P}=0,05)$ de acordo com o modelo da bainha empregada para a IA $(57,72 \%$ [71/123], 48,04\% [49/102] e 58,16\% [139/239], respectivamente para os grupos G1, G2 e G3). Menor incidência de refluxo de sêmen $(\mathrm{P}<0,05)$ foi observado para o modelo de baixa retenção residual de espermatozoides $(0,72 \%)$, frente aos modelos líderes do mercado internacional $(10,42 \%)$ e nacional (22,99\%; Experimento-3). Conclui-se que ocorre retenção residual de sêmen, independente do modelo de bainha utilizada para a IA. No entanto, a PES é influenciada pelo modelo e qualidade da bainha utilizada para inseminação artificial, fator que pode comprometer os índices de concepção de vacas sincronizadas para IATF.

Palavras-chave: Bovino. Gado de corte. IATF. Inseminação artificial. Fertilidade.

\section{Introduction}

After nearly a century of commercial artificial insemination (AI) in cattle, the technique still stands out because it offers innumerable benefits compared to natural mating, including the lower cost of bull maintenance, better sanitary control, and also promoting greater genetic improvement (López-
Gatius, 2012; Vishwanath, 2003). Additionally, the progress of semen cryopreservation has dramatically facilitated the genetic progress of beef and dairy cattle (Carvalho et al., 2013).

Considering the large environmental impact of livestock production, there are urgent requirements to improve the efficiency of different cattle 
production systems (Vries \& Boer, 2010). Advances in reproductive biotechnologies and an enhanced understanding of the dynamics of the bovine estrous cycle have made the development of protocols to manipulate the estrous cycle and control ovulation using natural and/or artificially synthesized hormones (Lamb \& Mercadante, 2016). Estrus synchronization and FTAI have increased the use of AI in beef cows and heifers (Bishop et al., 2017), making it possible to use large-scale AI, even in extensive breeding systems in tropical areas.

The success of AI programs is often estimated by the number of pregnant females after artificial insemination and by the final cost per calf produced through this technique (Edwards, Bo, Chandra, Atkinson, \& McGowan, 2015). Consequently, for an AI program to be truly effective, it must have a great production capacity, which will depend directly on the fertility of the herd and will be influenced by many factors, such as the health of the female reproductive tract and procedures used to conduct the AI technique, in addition to all of the physicochemical events involved in the gametes fertilization (Thomé et al., 2016).

Factors such as the optimization of management, efficiency of estrus detection, synchronization of estrus and ovulation, timing of AI, interval from thawing semen to AI, efficient hygiene, and health of cows, are indicated as key components for the establishment of appropriate fertility rates in AI programs (López-Gatius, 2012; L. Z. Oliveira et al., 2012; Richards, Spitzer, Newmand, \& Thompson, 1984; Wiltbank \& Pursley, 2014). Insemination efficiency also depends on innumerable factors, such as the genetic material quality, care taken in semen storage and handling, site of sperm deposition, number of sperms deposited in the female reproductive tract, and amount of accessory sperm cells available in the oviduct (Crespilho et al., 2014; Dalton, Nadir, Bame, \& Saacke 1999; Dalton et al., 2001; López-Gatius, 2012).

In recent years, AI protocols have been demonstrated efficient conception rates (Baruselli,
Sales, Sala, Vieira, \& Sá, 2012; Bishop et al., 2017). However, according to Carvalho et al. (2013), the AI technique can produce low fertility rates if the inseminator deposits the semen improperly in the female reproductive tract. Therefore, Pessoa et al. (2016) described the influence of the cover sheath brand and model used for AI on the decoupling rate of straws from the cover sheath applicator and semen reflux during the procedure, generating a residual waste of genetic material and a significative decrease in the number of sperm cells inseminated. The aim of this research was to test the hypothesis that the insemination cover sheaths employed for AI programs may influence the semen retention in artificial insemination gun trials and the conception rates of beef cows synchronized for fixed-time artificial insemination (FTAI).

\section{Materials and Methods}

\section{Ethical approval of animal use}

All procedures were approved by the Animal Care Committee of the College of Veterinary Medicine of Vassouras University (protocol number 008/2017), RJ, Brazil, according to the Brazilian Council for the Control of Animal Experimentation (CONCEA).

\section{Experiment 1}

French straws $(0.5 \mathrm{~mL})$ of cryopreserved bovine semen ( $n=400$ straws) from 68 bulls of different breeds and produced in different AI centers from Brazil and the USA were used in this experiment. Groups of four straws were thawed in a water bath $\left(36^{\circ} \mathrm{C}\right.$ for $\left.30 \mathrm{~s}\right)$ and the content of each group was deposited in a disposable $15 \mathrm{~mL}$ conical tube and used to repack three new French $0.5 \mathrm{~mL}$ straws $\left(\mathrm{IMV}^{\circledR}\right.$ Technologies, L'Aigle, France), composing samples with similar weight and volume characteristics, to ensure the standardization of experimental sperm batches. 
Each dose of repacked semen was weighed individually on a precision digital scale (A) and then mounted using one of the three models of artificial insemination cover sheaths $(n=100$ doses of semen/cover sheath tested): the main brand in the global market (G1); the main model in the Brazilian market (G2); and a national model identified as having low residual semen retention (G3).

Each cover sheath was individually weighed before (B) and after coupling the straws containing the semen $(C)$. Cover sheaths were mounted on a universal applicator $\left(\mathrm{IMV}^{\circledR}\right.$ Technologies, L'Aigle, France) for AI in cattle and the content of each dose of semen was completely discarded through the pressure exerted by the plunger of the applicator. After this procedure, each cover sheath, with straws yet to be coupled, was reweighed (D) and the percentage of seminal elimination (PSE) was obtained by the equation $[(\mathrm{C}-\mathrm{D} / \mathrm{A}) \times 100]$ and the semen retention rate (RR [\%]) was obtained by the equation [100 - PSE], according to each experimental group.

\section{Experiment 2}

This experiment was conducted in a single commercial farm located in Mato Grosso do Sul State, Brazil (Latitude: $18^{\circ} 30^{\prime} 24^{\prime \prime} \mathrm{S}$; Longitude: $54^{\circ} 45^{\prime} 36^{\prime \prime} \mathrm{W}$ ) during the breeding season.

Frozen semen packed in $0.5 \mathrm{~mL}$ straws from three Aberdeen Angus bulls were used in this experiment. All semen used had their post-thaw quality evaluated by the same veterinarian, presenting a total sperm motility of $55.32 \pm 4.23 \%$, total morphological defects of $26.72 \pm 4.19 \%$, and total sperm per straw of $13 \times 10^{6} \pm 2.63 \%$, according to the minimal quality standards recognized by Brazilian Breeding Soundness Evaluation Manual (Colégio Brasileiro de Reprodução Animal [CBRA], 2013). Straws of semen were thawed at $36^{\circ} \mathrm{C}$ for $30 \mathrm{~s}$ and randomly divided for assembly into conventional cover sheaths (123 in the international model [G1] and
102 using the national model [G2], as described in Experiment 1) or cover sheaths identified as having low residual semen reflux $(\mathrm{G} 3 ; \mathrm{n}=239)$ before insemination. The samples were used for the FTAI of primiparous Nelore cows $(\mathrm{n}=464), 50$ to 80 days postpartum, with a mean body condition score ( 1 to 5 scale) on the first day of the protocol of $2.6 \pm 0.36$ (Ayres et al., 2009) maintained on a pasture of Brachiaria decumbens with free access to water and mineral supplementation. Animals were divided into two management lots and were synchronized by placing a second-use intravaginal device containing $1.0 \mathrm{~g}$ of progesterone $\left(\mathrm{DIB}^{\circledR}\right.$, MSD Saúde Animal, São Paulo, Brazil) and $2.0 \mathrm{mg}$ of intramuscular (IM) estradiol benzoate $(2.0 \mathrm{~mL}$ Gonadiol ${ }^{\circledR}$, MSD Animal Health, São Paulo, Brazil) was administered on day 0 (D0) of the hormonal protocol. After eight days (D8), the progesterone implant was removed and $1.0 \mathrm{mg}$ of IM estradiol benzoate $\left(\right.$ Gonadiol $^{\circledR}$; MSD Saúde Animal, São Paulo, Brazil), $0.150 \mathrm{mg}$ of IM D-cloprostenol (2.0 $\mathrm{mL}$ Prolysis ${ }^{\circledR}$, Sintex, Argentina), and 400 IU of equine chorionic gonadotropin (eCG, Novormon ${ }^{\circledR}$, MSD Animal Health, São Paulo, Brazil) were injected. All animals were inseminated 44 to $48 \mathrm{~h}$ after implant removal by two trained AI technicians (performed similar numbers of inseminations with each cover sheath in testing). Pregnancy diagnoses were performed ultrasonographically 35 days after FTAI.

\section{Experiment 3}

\section{Semen evaluations}

All batches used for AI in this experiment were previously analyzed and selected by post-thaw semen quality, presenting an average total motility of $63.41 \pm 5.18$, plasma membrane integrity of $43.28 \pm 4.15$, total morphological defects of 23.13 \pm 4.88 , and total sperm/dose of $18.82 \times 10^{6} \pm 7.03$.

Sperm kinetics and concentration were evaluated by computer-assisted sperm analysis (CASA; 
ISAS $^{\circledR}$, Valencia, Spain). The software settings were those recommended by the manufacturer for the analysis of bull semen motility and concentration, according to Crespilho et al. (2017). Every sample constituted a minimum of five random fields and 2000 spermatozoa per analysis.

The plasma membrane integrity (PMI) was determined by the association of fluorescent probes of propidium iodide (PI; P4170, Sigma Aldrich St. Louis, Missouri, USA) and 6-carboxyfluorescein diacetate (CFDA; C5041, Sigma Aldrich, St. Louis, Missouri, USA), according to Crespilho et al. (2014). Stained samples were evaluated under an epifluorescence microscope at $400 \times\left(\right.$ Leika $^{\circledR}$, Solms, Germany) and two distinct groups of cells were identified: cells with intact plasma membranes (green fluorescence) or cells with damaged plasma membranes (red fluorescence). A total of 200 cells from each sample were evaluated.

Phase contrast microscopy was used for the morphological evaluation of sperm, at $1,000 \times$ magnification with immersion oil. An aliquot of semen was fixed in $2 \%$ buffered saline formalin solution, and each sample was wet-mounted using a drop of sample between a slide and coverslip. For the sperm cell morphological evaluation, 200 cells were considered.

\section{Animals and FTAI protocol}

A total of 859 multiparous Nelore or $1 / 2$ Nelore cows, 50 to 75 days postpartum, with a mean body condition score in the first day of the protocol $\geq$ 3 (1 to 5), according to Ayres et al. (2009), were used during the breeding season. Cows were kept in a Brachiaria brizantha pasture with free access to water and mineral salt supplementation, from a single commercial farm located in Mato Grosso do Sul State, Brazil (20 $\left.14^{\prime} 26^{\prime \prime} \mathrm{S} ; 56^{\circ} 22^{\prime} 42^{\prime \prime} \mathrm{W}\right)$.

Animals were divided into three management lots. All cows were synchronized using single-use intravaginal implants containing $1 \mathrm{~g}$ of progesterone
(Cronipress Monodose ${ }^{\circledR}$, Biogenesis Bagó, Curitiba, Brazil) and $2.0 \mathrm{mg}$ of IM estradiol benzoate $(2.0 \mathrm{~mL}$ of Bioestrogen ${ }^{\circledR}$; Biogenesis Bagó, Curitiba, Brazil) on day 0 (D0) of the hormonal protocol. After eight days (D8), progesterone implants were removed and $1.0 \mathrm{mg}$ of IM estradiol benzoate (Bioestrogen ${ }^{\circledR}$; Biogenesis Bagó, Curitiba, Brazil), $0.150 \mathrm{mg}$ of IM D-cloprostenol (Croniben ${ }^{\circledR}$; Biogenesis Bagó, Curitiba, Brazil), and 400 IU of equine chorionic gonadotrophin $\left(\right.$ Ecegon $^{\circledR}$; Biogenesis Bagó, Curitiba, Brazil) were administered. Artificial inseminations were performed 44 to $48 \mathrm{~h}$ after progesterone implant removal, using bovine semen packed in $0.5 \mathrm{~mL}$ straws previously selected by the quality standard (as presented before) from four Aberdeen Angus bulls. For inseminations, groups of five straws of each dose of semen were thawed at $36{ }^{\circ} \mathrm{C}$ for $30 \mathrm{~s}$ in an automatic system designed for thawing bull semen (WTA ${ }^{\circledR}$, Sertãozinho, Brazil) and randomly divided and mounted onto one of the three models of AI cover sheaths (as described in Experiment 1), following the same methodology as that in previous experiments. After each AI, the sheaths were visually inspected by the same technician and classified into two groups: sheaths with evidence (1) or an absence of semen retention (0). Conception rates were assessed by ultrasound exams 35 days after FTAI. Conception rates were assessed by ultrasound exams 35 days after FTAI.

\section{Statistical analyses}

All analyses were conducted using $\mathrm{SAS}^{\circledR}$ software (SAS Institute Inc., Cary, NC, USA). The percentage of seminal elimination and residual RR of semen (Experiment 1) were submitted to the normality test (Shapiro-Wilk) for the posterior analysis of variance using the PROC GLM command. The binomial variables represented by the pregnancy rates (Experiments 2 and 3) and the presence of residual semen retention post-AI were analyzed through PROC LOGISTIC command. Descriptive variables, such as management lot, 
cow body condition score, bull/semen batch, inseminator, motility, and concentration and PMI of the semen doses used for AI, were submitted to analysis of variance using the PROC GLM model (Experiments 2 and 3). For all tests and experiments, results were considered different when $P \leq 0.05$ and tending toward different when $0.05<P<0.10$.

\section{Results and Discussion}

Significant effects of cover sheath model on the residual RR and PSE were observed $(P=0.05$; Table 1), with G3 cover sheaths showing a smaller residual semen retention (and consequently higher semen elimination) compared to G2 cover sheaths (Experiment 1).

Table 1

In vitro evaluation of the percentage $( \pm \mathrm{SD})$ of seminal elimination $(\mathrm{PES}, \%)$ and residual retention rate of semen (RR, \%), according to the sheath used to administer doses of bovine semen (Experiment 1)

\begin{tabular}{cccc}
\hline Parameters & G1 & G2 & G3 \\
\hline PES (\%) & $91.7 \pm 3.01^{\mathrm{ab}}$ & $90.6 \pm 12.54^{\mathrm{b}}$ & $96.5 \pm 2.42^{\mathrm{a}}$ \\
RR (\%) & $7.3 \pm 3.00^{\mathrm{ab}}$ & $8.8 \pm 12.50^{\mathrm{b}}$ & $5.8 \pm 2.40^{\mathrm{a}}$ \\
\hline
\end{tabular}

a,b Different letters in the same line represent statistical differences $(P=0.05)$. G1 $(\mathrm{n}=100)$ : leading brand in the global market; G2 $(\mathrm{n}=100)$ : leading model in the Brazilian market; $\mathrm{G} 3(\mathrm{n}=100)$ : model identified as having a low residual RR of semen.

In Experiment 2, no differences $(P=0.31)$ were found when comparing conventional cover sheaths (G1 plus G2 groups; $\mathrm{n}=225$, conception rates $=$ $53.33 \%$ ) or low reflux cover sheaths (G3 group; $n$ $=239$, conception rate $=58.16 \%$ ). However, in the individual evaluation of the AI supply, differences were observed in the conception rates $(P=0.05)$ among cover sheath models after FTAI (Table 2). Additionally, the pregnancy per AI (P/AI) was influenced by the body condition score of cows at the beginning of the hormonal protocols $(P=0.03)$.

Table 2

Conception rates of primiparous Nelore cows $(n=464)$, according to the sheath model used to recover the artificial insemination (AI)-gun used for fixed-time artificial insemination (FTAI) (Experiment 2)

\begin{tabular}{cc}
\hline Groups & Conception rates $(\mathbf{\%}) \mathbf{n} / \mathbf{n}$ \\
\hline G1 & $57.72^{\mathrm{a}}(71 / 123)$ \\
G2 & $48.04^{\mathrm{b}}(49 / 102)$ \\
G3 & $58.16^{\mathrm{a}}(139 / 239)$ \\
\hline Total & $54.64(259 / 464)$ \\
\hline
\end{tabular}

a,b Different letters in the same column express statistical differences $(P=0.05)$. G1: leading brand in the global market; G2: leading model in the Brazilian market; G3: model identified as having a low residual RR of semen.

In Experiment 3, the conception rates were $58.96 \%(\mathrm{n}=181 / 307), 58.39 \%(\mathrm{n}=160 / 274)$, and $59.35 \%(n=165 / 278)$ for groups $\mathrm{G} 1, \mathrm{G} 2$, and G3, respectively, and did not differ among them $(P=0.48)$. There were no observed significative effects of bull/semen batches, body condition score, or management lot of cows, as well as their interactions, on the conception rates of FTAI cows $(P>0.05)$. However, a significant effect $(P<0.0001)$ of the cover sheath used for AI was observed on the incidence of residual semen retention (Table 3; Figure 1). 
Table 3

Effect of sheath model used for insemination on the conception rates of multiparous Nelore cows inseminated at a fixed-time, and semen retention rate ( $R R, \%)$ evaluated macroscopically after each insemination (Experiment 3$)$

\begin{tabular}{ccccc}
\hline Groups & Inseminated cows (n) & Conception (n) & Conception rates (\%) & RR (\%) \\
\hline G1 & 307 & 181 & 58.96 & $10.42^{\mathrm{b}}$ \\
G2 & 274 & 160 & 58.39 & $22.99^{\mathrm{c}}$ \\
G3 & 278 & 165 & 59.35 & $0.72^{\mathrm{a}}$ \\
\hline
\end{tabular}

a,b Different letters in the same column express statistical differences $(P<0.0001)$. G1: leading brand in the global market; G2: leading model in the Brazilian market; G3: model identified as having a low residual retention rate (RR, \%) of semen.

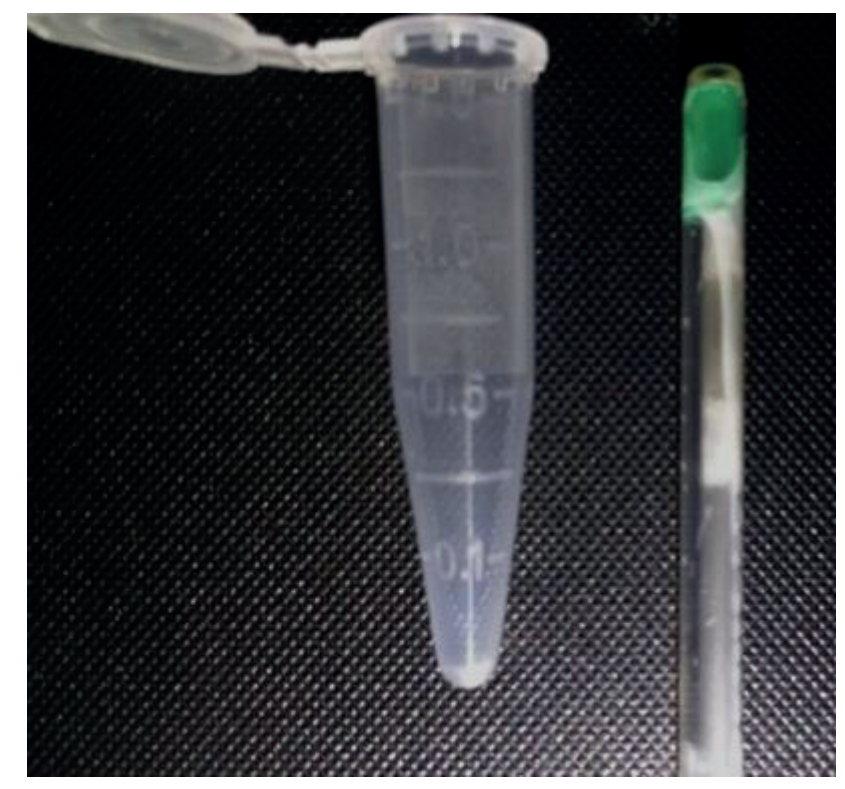

Figure 1. Macroscopic evaluation of the residual retention of semen after insemination (plastic microtube on the left representing a volume reference). Seminal reflux (arrow), determining reductions in the volume and number of sperm deposited in the female reproductive tract during artificial insemination (AI).

The efficiency of AI techniques depends, among many other factors, on the deposition of a sufficient number of normal spermatozoa into appropriate reproductive tract sites at the proper time of estrus (Lópes-Gatius, 2012). However, our study presents another aspect that can influence the results of the AI programs, which represents the relationship between the material quality used for AI and the number of sperms inseminated.
In Experiment 1, we observed a significant effect of the cover sheath model on both PSE and RR. Differences in the reflux rate of semen to the interior of the cover sheath applicator system have also been described by Carvalho et al. (2013). According to the authors, the retention of semen within the cover sheath may lead to a decrease in the number of sperms introduced into the uterus of the female during AI, which may compromise 
the conception rates. Verberckmoes et al. (2004) reported that a significant number of frozen-thawed bull spermatozoa remained in the insemination catheter $(9 \%$ to $19 \%)$ after $\mathrm{AI}$, indicating that the technique and material used for AI in cattle can influence the PSE.

The relationship between the number of inseminated spermatozoa with conception rates in AI programs (Andersson, Taponen, Koskinen, \& Dahlbom, 2004; Den Daas, De Jong, Lansbergen, \& Van Wagtendonk-de Leeuw, 1998; Bodmer et al., 2005) and FTAI (Crespilho et al., 2014) have been determined by previous studies, which indicated the possibility of decreased pregnancy rates when smaller inseminating doses are used.

Higher sperm concentration may increase fertilization rates (Nadir, Saacke, Bame, Mullins, \& Degelos, 1993) by supplying a greater number of accessory spermatozoa into the oviduct of cows (Dalton et al., 1999; Dejarnette, Saacke, Bame, \& Vogler, 1992). Therefore, the results of Experiment 2 suggest that the decreased conception rate observed for females inseminated with G2 cover sheaths (associated with higher seminal RR) can be attributed to the lower number of spermatozoa inseminated through this system. This suggests that there were increased insemination doses in the groups that had less sperm remaining in the AI cover sheath, probably promoting higher numbers of viable sperm in the reproductive tract and consequently in the oviduct, which explains the significant increase in conception rates in the G1 and G3 groups. In this sense, positive correlations were reported among increased insemination doses and the number of sperms reaching the oviduct of different species, such as mares (Cazales, FialaRechsteiner, Cavestany, \& Mattos, 2018) and cows (Saacke, Dalton, Nadir, Nebel, \& Bame, 2000). Crespilho et al. (2014) observed that an increase in the number of sperm cells used per insemination dose improves pregnancy rates by $\mathrm{AI}$ in Bos indicus lactating beef cows, supporting our results.
In addition to the sperm dose used for insemination, the semen quality has an important impact on the fertility rates of AI programs (B. M. Oliveira et al., 2014). Previous studies have reported an important compensatory effect of the semen quality on pregnancy per AI (Den Daas et al., 1998; Andersson et al., 2004; L. Z. Oliveira et al., 2013). In this sense, although $22.99 \%$ of cover sheaths in the G2 group indicated variable amounts of semen reflux (Experiment 3), the residual seminal retention did not influence the pregnancy rates of FTAI cows in this experiment. These results may be justified by the semen used for AI in this study, since only high-quality sperm samples (total motility $\geq 60 \%$, PMI $\geq 40 \%$, morphological defects $<30 \%$, and sperm concentration $>18 \times 10^{6}$ spermatozoa/dose) were used for AI in Experiment 3. These results hypothesize that small differences in the number of inseminated sperm (related to higher PES) did not compromise the pregnancy rates when highquality semen are used for inseminations. In this context, although several parameters of semen quality can influence the success of AI programs, sperm kinetics, PMI, and major morphological defects are more significative and determinants of high conception rates in the FTAI of beef cattle (L. Z. Oliveira et al., 2013), justifying the results of the fertility trial in the Experiment 3.

Little information is available about the management practices and supplies used by producers, who use $\mathrm{AI}$ and estrous synchronization in the USA (Johnson \& Dahlke, 2016), probably representing the same panorama from other important countries of beef cattle production worldwide. However, our results indicated that residual semen retention is influenced by the model and quality of the cover sheath used for AI. Therefore, we can conclude that even small details involved in insemination procedures can influence the performance and pregnancy rates of FTAI programs in beef cows. 


\section{Conclusions}

The cover sheath brand/model influences the PSE during the AI of bovine females, and higher rates of residual retention of semen in the applicator sheath may reduce the conception rate of synchronized beef cows submitted to FTAI.

\section{Conflict of Interest}

All authors declare that there is no conflict of interest.

\section{Acknowledgments}

The authors would like to thank the Norte Consultoria Agropecuária (Coxim, MS, Brazil) and Geneplan Reprodução Bovina (Campo Grande, MS, Brazil) for their invaluable support in the execution of FTAI protocols and experimental data collection. In addition, the authors are grateful to MSD Animal Health (São Paulo, Brazil) for their support with the protocol and hormones used in the second experiment of this work. We also would like to thank Editage (www.editage.com) for English language editing. The authors declare that this research did not receive any specific funding.

\section{References}

Andersson, M., Taponen, J., Koskinen, E., \& Dahlbom, M. (2004). Effect of insemination with doses of 2 or 15 million frozen-thawed spermatozoa and semen deposition site on pregnancy rate in dairy cows. Theriogenology, 61(7-8), 1583-1588. doi: 10.1016/j. theriogenology.2003.09.006

Ayres, H., Ferreira, R. M., Torres, J. R. S., Jr., Demétrio, C. G. B., Lima, C. G. de, \& Baruselli, P. S. (2009). Validation of body condition score as a predictor of subcutaneous fat in Nelore (Bos indicus) cows. Livestock Science, 123(2-3), 175-179. doi: 10.1016/j. livsci.2008.11.004

Baruselli, P. S., Sales, J. N. S., Sala, R. V., Vieira, L. M., \& Sá, M. F., Fo. (2012). History, evolution and perspectives of timed artificial insemination programs in Brazil. Animal Reproduction, 9(3), 139-
152. Retrieved from http://s3.amazonaws.com/hostarticle-assets/animreprod/5b5a6055f7783717068b4 $6 \mathrm{~d} 7$ /fulltext.pdf

Bishop, B. E., Thomas, J. M., Abel, J. M., Poock, S. E., Ellersieck, M. R., Smith, M. F., \& Patterson, D. J. (2017). Split-time artificial insemination in beef cattle: III. Comparing fixed-time artificial insemination to split-time artificial insemination with delayed administration of $\mathrm{GnRH}$ in postpartum cows. Theriogenology, 99(1), 48-52. doi: 10.1016/j. theriogenology.2017.04.046

Bodmer, M., Janett, F., Hassig, M., Den Daas, N., Reichert, P., \& Thun, R. (2005). Fertility in heifers and cows after low dose insemination with sexsorted and non-sorted sperm under field conditions. Theriogenology, 64(7), 1647-1655. doi: 10.1016/j. theriogenology.2005.04.011

Colégio Brasileiro de Reprodução Animal (2013). Manual de Exame Andrológico e Avaliação de Sêmen Animal (3a ed.). Belo Horizonte: CBRA.

Carvalho, P. D., Souza, A. H., Sartori, R., Hackbart, K. S., Dresch, A. R., Vieira, L. M.,... Wiltbank, M. C. (2013). Effects of deep-horn AI on fertilization and embryo production in superovulated cows and heifers. Theriogenology, 80(9), 1074-1081. doi: 10.1016/j.theriogenology.2013.08.008

Cazales, N., Fiala-Rechsteiner, S. M., Cavestany, D., \& Mattos, R. C. (2018). Insemination dose and site with frozen semen affects the sperm transport and inflammatory response in mares? Journal of Equine Veterinary Science, 66(1), 109-110. doi: 10.1016/j. jevs.2018.05.155

Crespilho, A. M., Chiaradia, L., Cortez, A., Dinelli, M. V., Papa, F. O., Gomes, G. M., \& Peixoto, K. C., Jr. (2017). Sensitivity evaluation of the computerassisted sperm analysis (CASA) in the determination of frozen-thawed bull semen concentration. Brazilian Journal of Veterinary Research and Animal Science, 54(3), 247-252. doi: 10.11606/issn.1678-4456. bjvras.2017.127773

Crespilho, A. M., Papa, F. O., Sá, M. F., Fº., Guasti, P. N., Dell'Aqua, J. A., Jr., Vasconcelos, J. L. C.,... Martins, A., Jr. (2014). The influence of insemination dose on pregnancy per fixed-time artificial insemination in beef cows is affected by semen extender. Animal Reproduction, 11(1), 3-10. Retrieved from https:// www.researchgate.net/publication/261876297_The _ influence_of_insemination_dose_on_ pregnancy per_fixed-time_artificial_insemination_in_beef_cows_is_affected_by_semen_extender 
Dalton, J.C., Nadir, S., Bame, J. H., \& Saacke, R. G. (1999). Effect of a deep uterine insemination on spermatozoa accessibility to the ovum in cattle: a competitive insemination study. Theriogenology, 51(5), 883-890. doi: 10.1016/S0093-691X(99)00035-7

Dalton, J. C., Nadir, S., Bame, J. H., Noftsinger, M., Nebel, R. L., \& Saacke, R. G. (2001). Effect of time of insemination on number of accessory sperm, fertilization rate, and embryo quality in nonlactating dairy cattle. Journal of Dairy Science, 84(11), 24132418. doi: $10.3168 /$ jds.S0022-0302(01)74690-5

Dejarnette, J. M., Saacke, R. G., Bame, J., \& Vogler, C. J. (1992). Accessory sperm: their importance to fertility and embryo quality and attempts to alter their numbers in artificially inseminated cattle. Journal of Animal Science, 70(2), 484-491. doi: 10.3168/jds. S0022-0302(92)77809-6

Den Daas, J. H., De Jong, G., Lansbergen, L. M., \& Van Wagtendonk-De Leeuw, A. M. (1998). The relationship between the number of spermatozoa inseminated and the reproductive efficiency of individual dairy bulls. Journal of Dairy Science, $81(6)$, 1714-1723. doi: 10.3168/jds.S00220302(98)75739-X

Edwards, S. A. A., Bo, G. A., Chandra, K. A., Atkinson, P. C., \& McGowan, M. R. (2015). Comparison of the pregnancy rates and costs per calf born after fixedtime artificial insemination or artificial insemination after estrus detection in Bos indicus heifers. Theriogenology, 83(1), 114-120. doi: 10.1016/j. theriogenology.2014.08.017

Johnson, S. K., \& Dahlke, G. (2016). Production practices and value of artificial insemination and estrus synchronization programs of United States beef producers. The Professional Animal Scientist, 32(1), 90-98. doi: 10.15232/pas.2015-01440

Lamb, G. C., \& Mercadante, V. R. G. (2016). Synchronization and artificial insemination strategies in beef cattle. Veterinary Clinics: Food Animal Practice, 32(2), 335-347. doi: 10.1016/j. cvfa.2016.01.006

López-Gatius, F. (2012). Factors of a noninfectious nature affecting fertility after artificial insemination in lactating dairy cows. A review. Theriogenology, 77(6), 1029-1041. doi: 10.1016/j. theriogenology.2011.10.014

Nadir, S., Saacke, R. G., Bame, J., Mullins, J., \& Degelos, S. (1993). Effect of freezing and dosage of sperm on number of accessory sperm, fertility, and embryo quality in artificially inseminated cattle.
Journal of Animal Science, 71(1), 199-204. doi: $10.2527 / 1993.711199 x$

Oliveira, B. M., Arruda, R. P., Thomé, H. E., Maturana, M., Fº, Oliveira, G., Guimarães, C., Celeghini, E. C. C. (2014). Fertility and uterine hemodynamic in cows after artificial insemination with semen assessed by fluorescent probes. Theriogenology, 82(5), 767-772. doi: 10.1016/j.theriogenology.2014.06.007

Oliveira, L. Z., Arruda, R. P., Andrade, A. F. C., Celeghini, E. C. C., Reeb, P. D., Martins, J. P. N., Lima, V. F. M. H. (2013). Assessment of in vitro sperm characteristics and their importance in the prediction of conception rate in a bovine timed-AI program. Animal Reproduction Science, 137(3-4), 145-155. doi: 10.1016/j.anireprosci.2013.01.010

Oliveira, L. Z., Arruda, R. P., Andrade, A. F. C., Santos, R. M., Beletti, M. E., Peres, R. F. G.,... Lima, V. F. M. H. (2012). Effect of sequence of insemination after simultaneous thawing of multiple semen straws on conception rate to timed AI in suckled multiparous Nelore cows. Theriogenology, 78(8), 1800-1813. doi: 10.1016/j.theriogenology.2012.07.007

Pessoa, G. A., Martini, A. P., Baioco, A. P., Trajano, J. G., Weigert, J. M., Minela, T.,... Rubin, M. I. B. (2016). Refluxo de espermatozoides em bainhas utilizadas para inseminação artificial em bovinos. Anais da Reunião Anual da Sociedade Brasileira de Tecnologia de Embriões, Foz do Iguaçu, PR, Brasil, 30. Recuperado de http://www.sbte.org.br/arquivos/ anais/anais-2016.pdf

Richards, M. W., Spitzer, C., Newmand, S. K., \& Thompson, C. E. (1984). Bovine pregnancy and nonreturn rates following artificial insemination using a covered sheath. Theriogenology, 21(6), 949957. doi: 10.1016/0093-691X(84)90388-1

Saacke, R. G., Dalton, J. C., Nadir, S., Nebel, R. L., \& Bame, J. H. (2000). Relationship of seminal traits an insemination time to fertilization rate and embryo quality. Animal Reproduction Science, 60-61(2), 663-677. doi: 10.1016/S0378-4320(00)00137-8

Thomé, H. E., Arruda, R. P., Oliveira, B. M. M., Maturana, M., F'., Oliveira, G. C., Guimarães, C. F.,... Celeghini, E. C. C. (2016). Uterine lavage is efficient to recover endometrial cytology sample and does not interfere with fertility rate after artificial insemination in cows. Theriogenology, 85(9), 15491554. doi: 10.1016/j.theriogenology.2016.01.014

Verberckmoes, S., Soom, A. V., Pauw, I., Dewulf, J., Vervaet, C., \& Kruif, A. (2004). Assessment of a new utero-tubal junction insemination device in 
dairy cattle. Theriogenology, 61(1), 103-115. doi: 10.1016/S0093-691X(03)00186-9

Vishwanath, R. (2003). Artificial insemination: the state of the art. Theriogenology, 59(2), 571-584. doi: 10.1016/S0093-691X(02)01241-4
Vries, M., \& Boer, I. J. M. (2010). Comparing environmental impacts for livestock products: a review of life cycle assessments. Livestock Science, 128(1-3), 1-11. doi: 10.1016/j.livsci.2009.11.007

Wiltbank, M. C., \& Pursley, J. R. (2014). The cow as an induced ovulator: timed AI after synchronization of ovulation. Theriogenology, 81(1), 170-185. doi: 10.1016/j.theriogenology.2013.09.017 
